\title{
Phytodiversity and Phytosociology of Riparian Trees Along the Elevation Gradient In The Pamba River, Southern Western Ghats, India
}

Joby Paul ( $\square$ jobypaulses@gmail.com )

ST. Thomas' College [Autonomous], Thrissur, Kerala https://orcid.org/0000-0002-7880-0150

\section{E S Adithya}

Mahatma Gandhi University School of Environmental Sciences

Nisha P

St. Xaviers College for Woman, Aluva, Kerala

\section{Rogimon P Thomas}

CMS College, Kottayam, Kerala

\section{Sankaran K S Unni}

Mahatma Gandhi University School of Environmental Sciences

\section{Research}

Keywords: Quadrat, Shannon-Weiner's Index, IVI, Stand type, DBH, TWINSPAN, Dispersion, Regeneration, Restoration

Posted Date: May 25th, 2021

DOI: https://doi.org/10.21203/rs.3.rs-546271/v1

License: (c) (i) This work is licensed under a Creative Commons Attribution 4.0 International License. Read Full License 


\section{Abstract}

\section{Background}

The riparian vegetation along the tropical rivers become threatened due to anthropogenic interference. The tree species diversity and distribution along longitudinal and transversal dimensions is variable and has a pivotal role in the river ecology. The data on the riparian tree species diversity and distribution is inevitable for the nature-based restoration efforts. To test the variability along with the river profile, we investigated the tree species diversity and phytosociology in the tropical river Pamba, Southern Western Ghats. Variation of elevation (701-1923m asl Highrange; 71-700m asl Highland; 8-70m asl Midland and $<7.0 \mathrm{~m}$ asl Lowland) as an indicator of topographic species diversity, we laid a total of $54 \times 3$ quadrats and data were analyzed with Excel and PC-Ord.

Results

Shannon-Wiener's diversity is uniform (1.43689-1.84841) and showed homogeneity (Multiple site similarity index $=0.825396825)$. Humboldtia vahliana, Neolamarckia cadamba, Vateria indica and Syzygium hemisphericum were showed the highest Importance Value Index. DBH size class (15$>331 \mathrm{~cm}$ ) demonstrated a reverse ' $\mathrm{J}$ ' shaped curve. The tree density and total basal area demonstrated an increasing trend from Lowland to Highrange. Validation of Quadrat data with TWINSPAN and BraunBlanquet table analysis indicated Ochreinauclea missionis-Ficus hispida-Neolamarckia cadamba in Lowland, Mallotus philippensis-Macaranga peltata-Ficus hispida in Midland, Madhuca neriifoliaHydnocarpus alpina-Humboldtia vahliana in Highland and Symplocos cochinchinensis var. laurinaSyzygium hemisphericum-Cullenia exarillata in Highrange as dominant stand types. Reciprocal Averaging and Hierarchical Clustering revealed unequivocal classification of quadrats following species composition and elevation. Clumped dispersion was noticed in the Midland and Highland. High regeneration of Madhuca neriifolia, Hopea ponga and Humboldtia vahliana were observed along the elevation gradient.

\section{Conclusions}

The present research illustrated that the species diversity of riparian forest in the Pamba river is high and comparable with similar tropical rivers. The phytodiversity, phytosociology and regeneration data are significant for developing a conservation strategy of the anthropogenically fragmented Pamba river. Based on the stand type and regeneration data, Madhuca neriifolia, Hopea ponga, Humboldtia vahliana and Ochreinauclea missionis were suitable for buffer design and restoration along with the Pamba river profile.

\section{Full Text}

Due to technical limitations, full-text HTML conversion of this manuscript could not be completed. However, the manuscript can be downloaded and accessed as a PDF. 


\section{Figures}

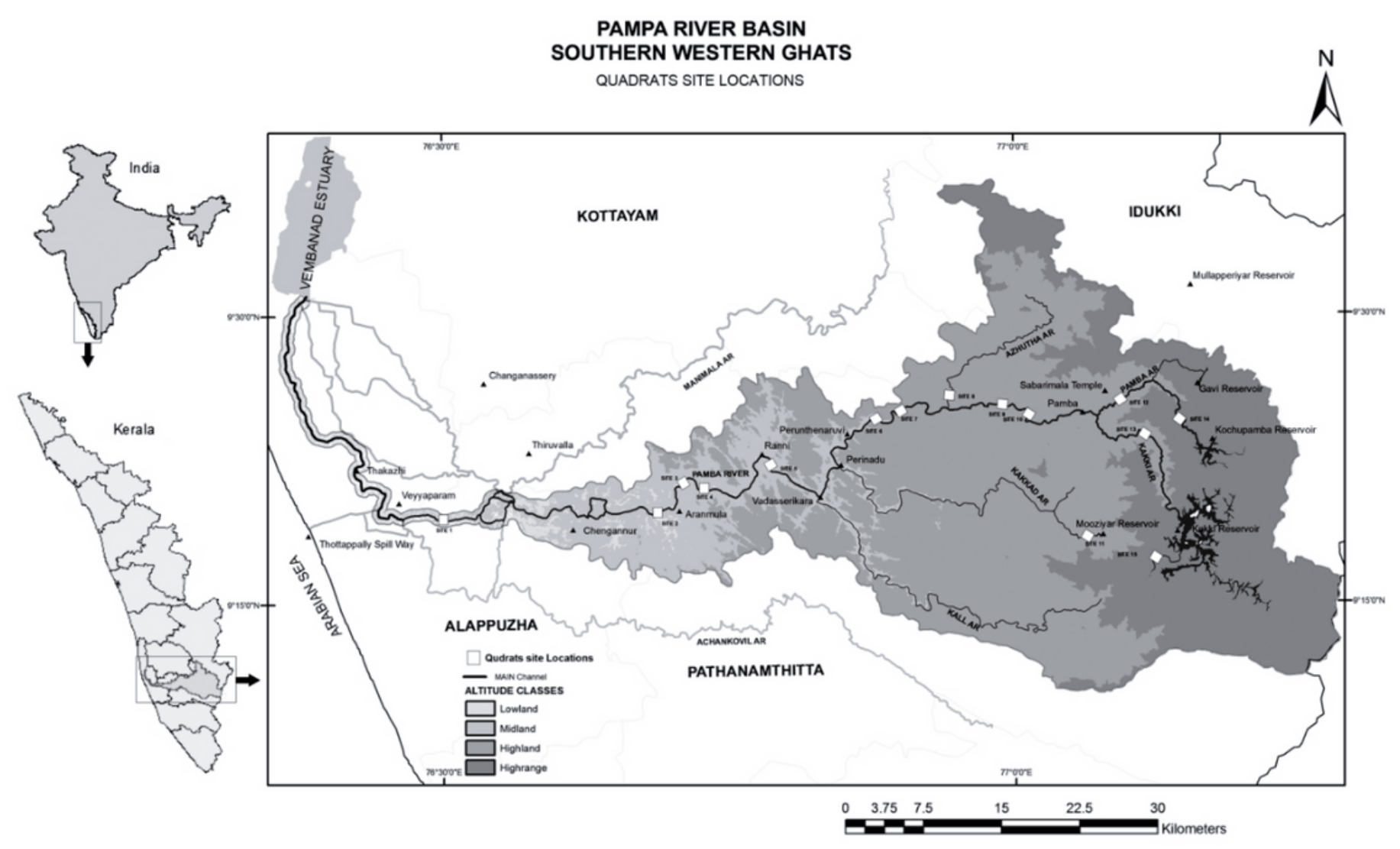

Figure 1

Map of the Pamba river basin with quadrat locations. Note: The designations employed and the presentation of the material on this map do not imply the expression of any opinion whatsoever on the part of Research Square concerning the legal status of any country, territory, city or area o bbnhjr of its authorities, or concerning the delimitation of its frontiers or boundaries. This map has been provided by the authors. 


\section{Species area curve}

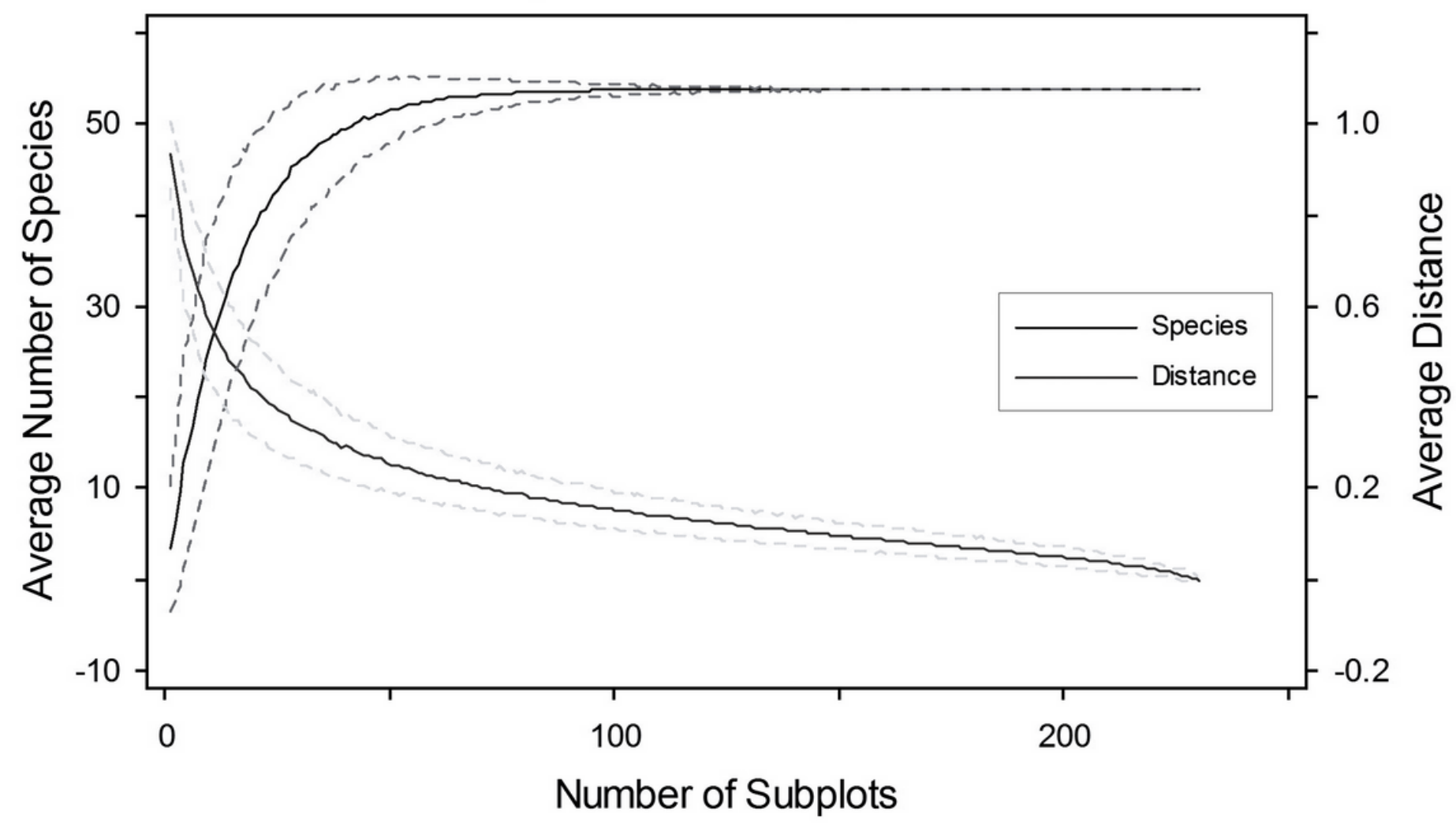

Figure 2

Species-area curve of 54 quadrats from riparian forests of Pamba river basin (The species are nested based on the highest to the lowest based on the number of individuals). 


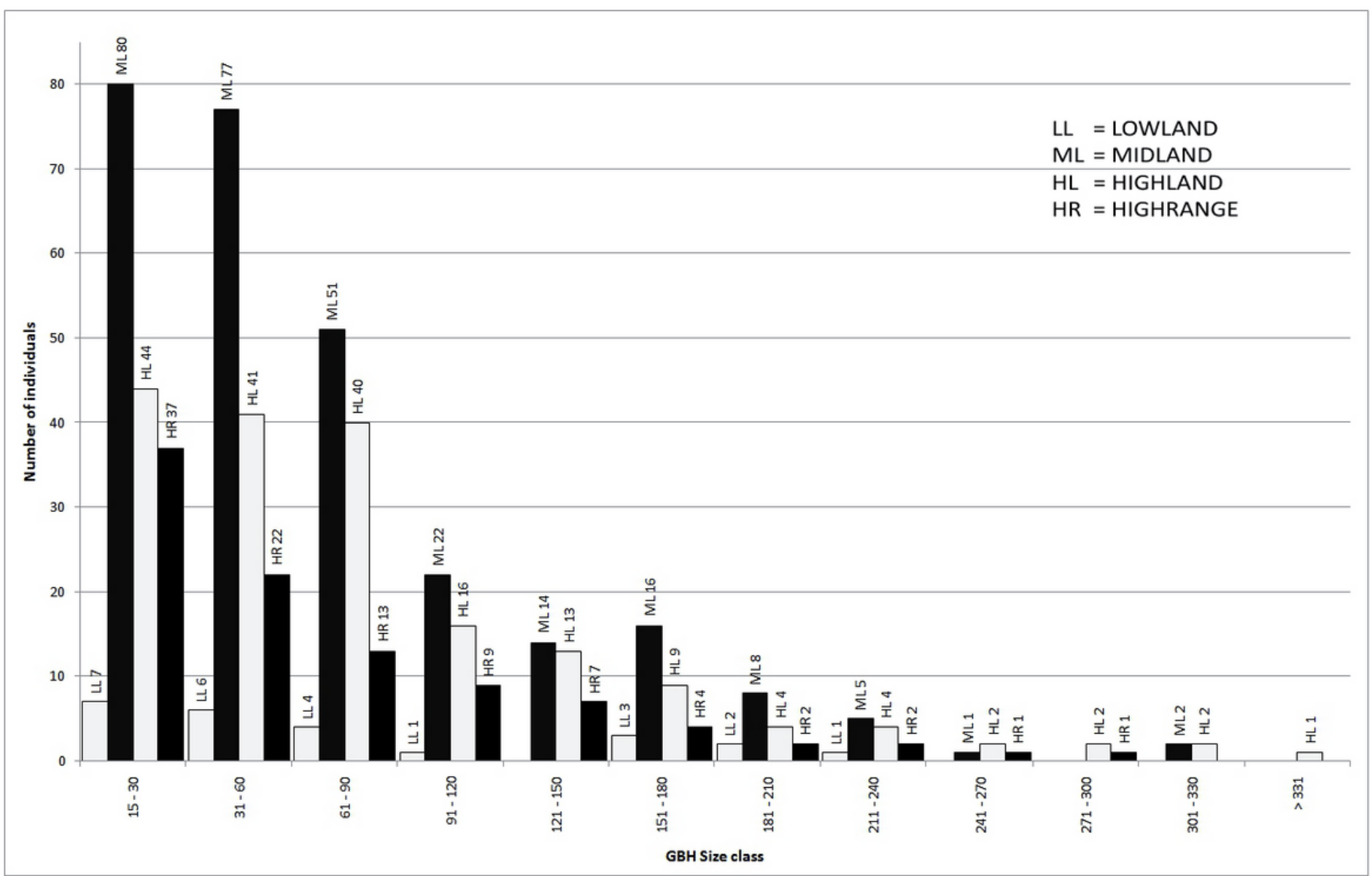

Figure 3

GBH size class in the riparian forests reaches of Pamba river, Kerala. $\mathrm{LL}=$ lowland, $\mathrm{ML}=$ Midland, $\mathrm{HL}=$ Highland and $\mathrm{HR}=$ Highrange. 


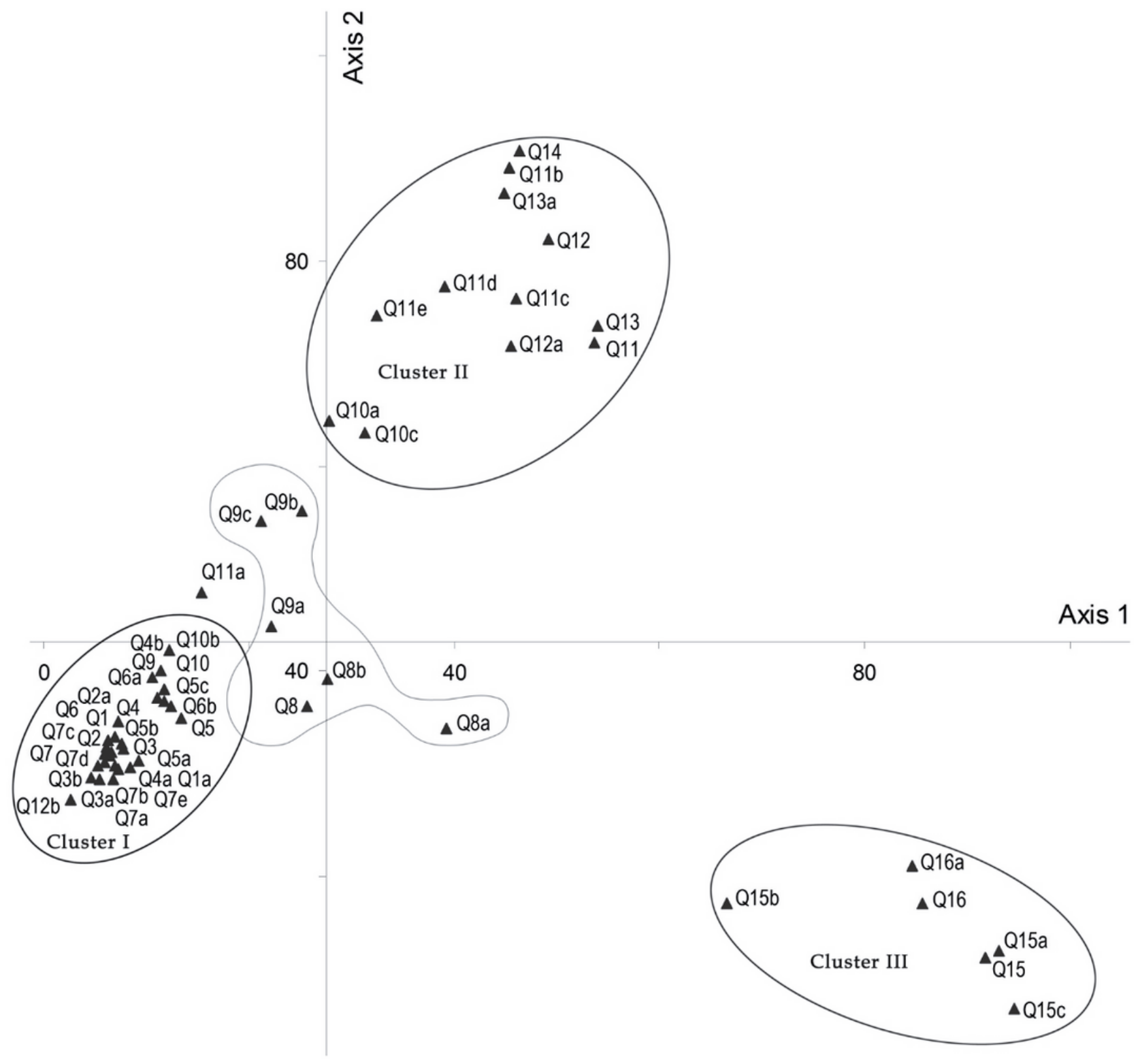

Figure 4

RA diagram of different riparian forest reaches of Pamba river 665 basin. ( $\boldsymbol{\Lambda}=$ quadrat sites. Cluster I is a combination of Lowland and Midland regions of the river reach, Cluster II represents the Highland and Cluster III represents Highrange. An outlier group which belongs to Midland region is represented in circular line. 


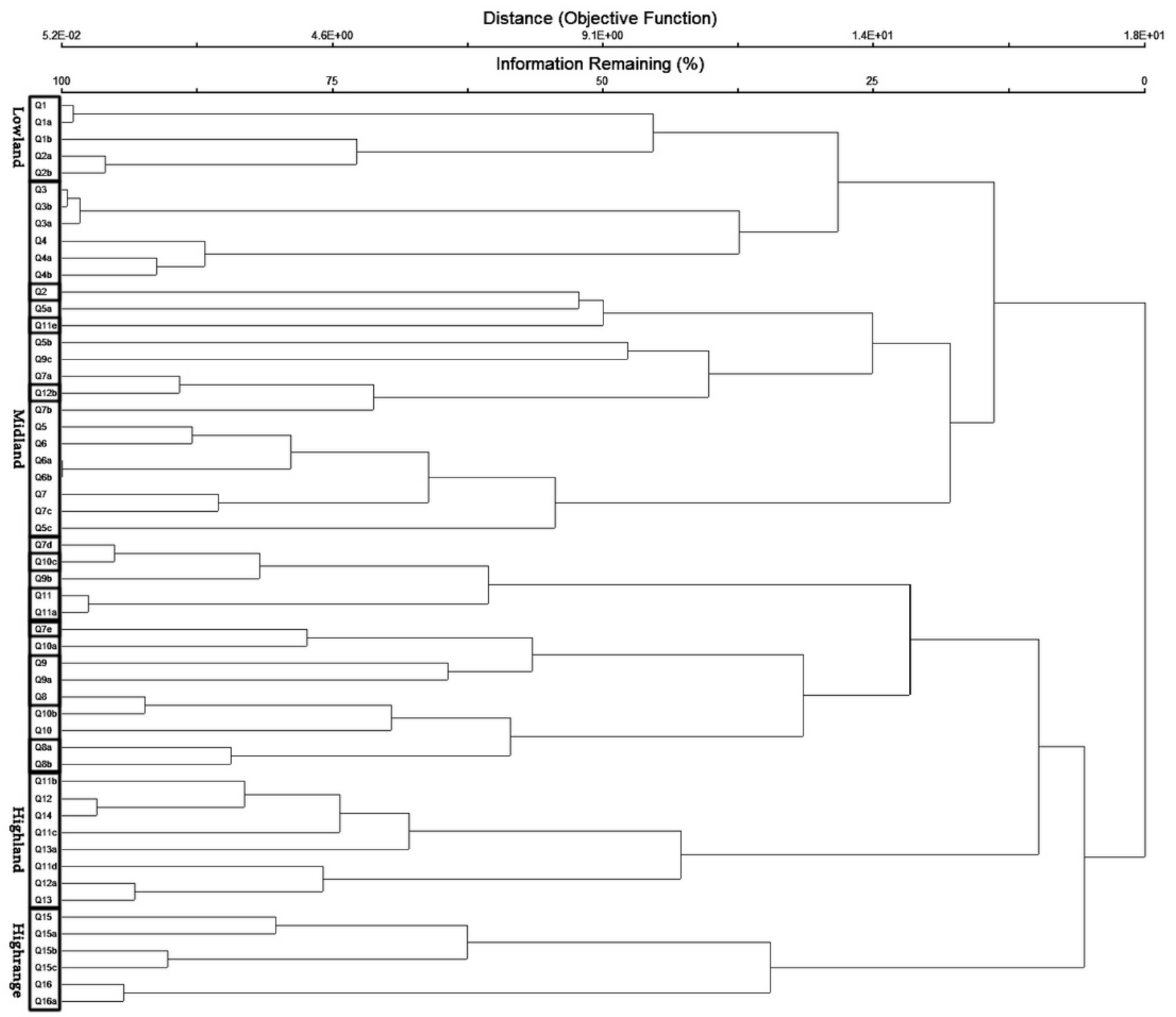

Figure 5

Hierarchical clustering diagram of 54 quadrat sites in 4 reaches of Pamba river. 
TWO-WAY ORDERED TABLE

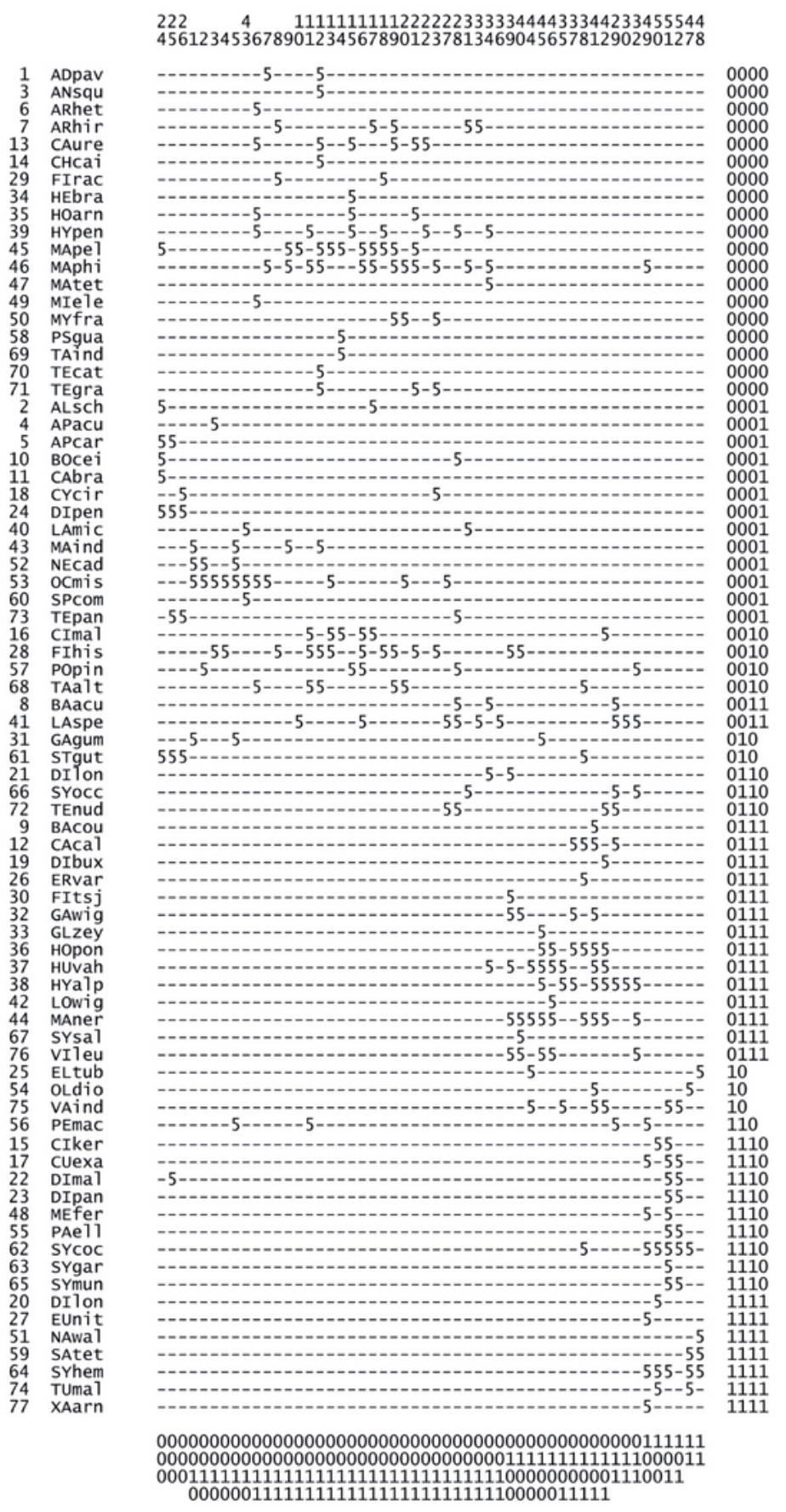

\section{Figure 6}

Two-Way ordered table of TWINSPAN of 52 quadrats in 4 reaches of Pamba river. 